\title{
Calcite buffer effects in electrokinetic remediation of
}

\section{clopyralid-polluted soils}

6 López-Vizcaíno, R. ${ }^{\text {a,c,*,1, }}$, dos Santos, E.V ${ }^{b}$., Yustres, A. ${ }^{c}$, Rodrigo, M.A. ${ }^{\text {d }}$, Navarro, V.c, 7 Martínez-Huitle, C.A. ${ }^{\mathrm{a}}$

$9{ }^{a}$ Institute of Chemistry, Federal University of Rio Grande do Norte, Campus 10 Universitario, 59078-970 Natal, Brazil.

$11{ }^{\mathrm{b}}$ School of Science and Technology, Federal University of Rio Grande do Norte, Campus 12 Universitario, 59078-970 Natal, Brazil.

$13{ }^{\mathrm{c}}$ Geoenvironmental Group, Civil Engineering School, University of Castilla-La Mancha, 14 Avda. Camilo José Cela s/n, 13071 Ciudad Real, Spain.

$15{ }^{\mathrm{d}}$ Department of Chemical Engineering, Faculty of Chemical Sciences \& Technologies, 16 University of Castilla-La Mancha, Campus Universitario s/n, 13071 Ciudad Real, Spain.

18 * Corresponding author, Rubén López-Vizcaíno, ruben.lopezvizcaino@uclm.es //

19 r.lopezvizcaino@gmail.com.

20 'Permanent address of Rubén López-Vizcaíno is Geoenvironmental Group, Civil Engineering School, 21 University of Castilla-La Mancha, Avda. Camilo José Cela s/n, 13071 Ciudad Real, Spain. 


\section{ABSTRACT}

23 This work presents a study of the dissolution-precipitation processes of calcite in soil

24 undergoing electrokinetic remediation processes. For this purpose, a numerical inspection

25 of one of these processes in a calcareous soil (10\% calcite content) contaminated with an

26 of the organochlorine acid herbicide (3,6-dichloro-2-pyridinecarboxylic acid) was carried

27 out. The numerical tool used to perform this analysis was the Multiphysics for EKR

28 (M4EKR), a module programmed by the authors in the COMSOL Multiphysics platform.

29 A detailed analysis of the $\mathrm{pH}$, the distribution of species that have a significant influence

30 on soil buffering capacity (carbonates and calcite), as well as the pollutant, has been

31 performed. In this way, the kinetics of the calcite dissolution-precipitation processes have

32 been analysed in order to determine the $\mathrm{pH}$ of the water in the pores and, therefore, how

33 it directly affects the effectiveness of the treatment. Additionally, a sensitivity analysis of

34 the selected EKR process has been carried out at different values of the rate of calcite

35 dissolution due to the uncertainty associated with the reactive surface area parameter.

\section{$37 \quad$ KEYWORDS}

38 Electrokinetic soil remediation, Multiphysics simulation, soil buffering capacity,

39 herbicide, M4EKR, calcite 


\section{INTRODUCTION}

44 The application of an electrical potential gradient between electrodes located in a soil activates a series of electrokinetic transport mechanisms capable of mobilising water

46 (electroosmosis), ionic species (electromigration) and even charged particles

47 (electrophoresis). Specifically, this technique is called electrokinetic remediation (EKR)

48 when it is applied to contaminated soils with the aim of mobilizing polluting species to

49 controlled extraction points [1-4]. The coupling of the above-mentioned transport mechanisms and the fact that, these treatments can be successfully applied in soils with

51 low hydraulic permeability, where Darcy flow is very limited, makes EKR technology a very versatile technique and consequently, an efficient and competitive alternative for treating pollution events with different compounds such as heavy metals [5-8], PAH [9-

54 13] or pesticides [14-18].

Regarding the EKR processes, the electrolysis of water is also an important electrochemical reaction developed on the electrode surface. This process simultaneously generates high concentrations of protons $\left(\mathrm{H}^{+}\right)$by the oxidation reaction of water on the anodic surface and hydroxyl ions $\left(\mathrm{OH}^{-}\right)$in the cathodic reduction reaction. The changes in the concentration of $\mathrm{H}^{+}$and $\mathrm{OH}^{-}$are reflected in the generation of an important $\mathrm{pH}$

60 gradient in the soil located between anodes and cathodes.

61 The $\mathrm{pH}$ changes generated in the vicinity of the electrodes depend on the amount of electro-generated $\mathrm{H}^{+}$and $\mathrm{OH}^{-}$and, in turn, on the electrical potential gradient applied in the process. However, the $\mathrm{pH}$-variations observed in the rest of the domain are determined

64 by the mobility of the acidic and alkaline fronts, from the anodic and cathodic zones 65 respectively. The transport of the $\mathrm{pH}$ front is mainly due to the electromigratory flow of $66 \mathrm{H}^{+}$and $\mathrm{OH}^{-}$species to the opposite sign electrodes and advective/diffusive processes, all 67 of which are strongly influenced by soil buffering capacity [19-24]. Generally, soil 
buffering capacity is defined by the contribution of different processes: (i)

69 protonation/deprotonation of substances present in the porewater, adsorption/desorption and ion exchange between the soil and the porewater and (iii) dissolution-precipitation of minerals [25].

72 At this point it is important to stress the importance of $\mathrm{pH}$ changes in EKR treatments.

73 This variable directly influences the chemical speciation of the substances present in soil and porewater, conditioning their ionic nature. Consequently, the $\mathrm{pH}$ of the system can determine the predominant mechanism of transport of chemical species in the soil.

In order to have a global understanding of the evolution of $\mathrm{pH}$ in an EKR process, it is necessary to improve the knowledge of the interactions attained between the electrokinetic transport phenomena and the physical, chemical and electrochemical processes that take place in an EKR treatment. The main objective of this work is to evaluate the influence of soil buffering capacity on the performance of an EKR process.

81 For this purpose, a numerical analysis of the EKR treatment of a calcareous soil with a 82 calcite content of $10 \%$, contaminated with clopyralid (3,6-dichloro-2-pyridinecarboxylic 83 acid, a common acid herbicide) was performed. Specifically, this study has evaluated the effects generated by the calcite dissolution-precipitation processes on the general behaviour of the EKR process and their importance for a better understanding of this type 86 of treatment.

87 The numerical tool used was the M4EKR module, Multiphysics for EKR [26]. M4EKR is a numerical model developed by the authors as a result of the knowledge gained over

89 the last years in the treatment of contaminated soils using electrokinetic techniques [27-

90 35]. The M4EKR model has been implemented in COMSOL Multiphysics and is capable

91 of simulating the general behaviour trends of an EKR process by solving a coupled 
92 problem of reactive transport and electric field. This makes the M4EKR module a

93 powerful computational tool that has been used to carry out different studies [36-38].

94 In this work, an assessment of the spatial distribution of the concentration of the species

95 that have a significant influence on soil buffering capacity (carbonates and calcite) was

96 performed. The relationship between the observed behaviour and the $\mathrm{pH}$ profiles obtained

97 is also analysed, as well as the direct influence on the performance of the simulated EKR

98 process. Additionally, and due to the difficulties in accurately predicting the kinetics of

99 calcite dissolution-precipitation, associated with the uncertainty of the reactive surface

100 area [39], a sensitivity analysis of the selected EKR process was performed using different

101 values of this parameter, which is equivalent to different levels of the rate of calcite

102 dissolution. Consequently, this study provides useful information on the influence of soil

103 buffer capacity on the general performance of an EKR process applied to the

104 decontamination of a calcareous soil with acidic contaminants.

\section{2. CONCEPTUAL MODEL AND NUMERICAL IMPLEMENTATION}

106 M4EKR is a reactive transport model applied to unsaturated porous media. It is a very

107 flexible numerical tool. Its adaptability and capacity for gradual implementation of

108 improvements are easy by the fact that the base module has been programmed in a

109 multiphysical environment. [26].

110 For conceptual simplification, the M4EKR version employed in this work does not

111 consider gas transport and the deformability of the soil. Due to the small scale of the

112 simulated tests (laboratory scale), it is acceptable to assume isothermal conditions (298

$113 \mathrm{~K})$. Given these simplifications, it is clear that the model will not perfectly match the

114 actual behaviour in an EKR process. However, this is not a limitation in the scope of the

115 work, since the aim is to improve phenomenological understanding and not to replicate a 
116 real case. Soil buffering capacity is provided by: chemical reactions with proton

117 consumption/production (see Table 4), and dissolution-precipitation of calcite [40]. The

118 adsorption/desorption processes onto the soil were not consider. As a novelty, the

119 M4EKR version used in this work has been improved with the implementation of a kinetic

120 model of calcite dissolution/precipitation, extrapolable to any other mineral if present.

121 Appendix A presents the basic mathematical formulation employed in module M4EKR.

122 A more detailed description of the formulation can be found in literature [26].

\section{2.1. Calcite mass balance}

124 The evolution of the mass of calcite is obtained solving the mass balance equation

$125 \frac{d M_{\text {calcite }}}{d t}=R_{\text {calcite }}$

126 where $M_{\text {calcite }}$ is the total mass of calcite $\left(\mathrm{mol} / \mathrm{m}^{3}\right)$ and $R_{\text {calcite }}$ is the calcite 127 production/consumption rate $\left(\mathrm{mol} \mathrm{m}^{-3} \mathrm{~s}^{-1}\right)$.

\subsection{Kinetic of calcite precipitation/dissolution}

129 The calcite production/consumption rate, $R_{\text {calcite }}\left(\mathrm{mol} \mathrm{m}^{-3} \mathrm{~s}^{-1}\right)$, has been estimated by a 130 general equation provided by Lasaga [41]:

$$
R_{\text {calcite }}= \pm k_{\text {calcite }} \cdot \phi \cdot S r \cdot \rho_{w} \cdot S_{\text {calcite }} \cdot\left(1-\Omega_{\text {calcite }}^{\theta}\right)^{\eta}
$$

132 where $k_{\text {calcite }}$ is the kinetic constant $\left(\mathrm{mol} \mathrm{s}^{-1} \mathrm{~m}^{-2}\right)$ of dissolution (negative value) or precipitation (positive value) processes, $S_{\text {calcite }}$ is the reactive surface area $\left(\mathrm{m}^{2} \mathrm{~kg}_{\mathrm{H}_{2} \mathrm{O}}^{-1}\right)$, and

$134 \Omega_{\text {calcite }}$ is the saturation ratio. Finally, $\theta$ and $\eta$ are empirical parameters that determine the

135 relation between reaction rate and saturation ratio. The parameters selected for calcite 136 were $\theta=0.5$ and $\eta=2$ [42]. A reference value for $S_{\text {calcite }}$ was extracted from literature

137 [42]. The parameters $\phi, S r$ and $\rho_{w}$ correspond to the soil porosity, saturation degree and 
138 water density. The saturation ratio $\left(\Omega_{\text {calcite }}\right)$ is estimated using the Eq. (3) where $K_{s, \text { calcite }}$

139 is the solubility constant of calcite [43] and IAP is the ionic activity product, calculated

140 as indicated in Eq. (4) where $a_{\mathrm{Ca}^{+2}}$ and $a_{\mathrm{CO}_{3}{ }^{-2}}$ are the activities of $\mathrm{Ca}^{2+}$ y $\mathrm{CO}_{3}{ }^{2-}$

141 respectively.

$142 \Omega_{\text {calcite }}=\frac{I \text { AP } \text { calcite }}{K_{S} \text {, calcite }}$

$143 \quad$ IAP calcite $=a_{\mathrm{Ca}^{2+}} \cdot a_{\mathrm{CO}_{3}{ }^{2-}}$

144 The kinetic constant $\left(k_{\text {calcite }}\right)$ has been defined using a model that takes into account the

145 influence additional mechanisms in the value of $k_{\text {calcite. }}$ In this case, a dependence on the

146 activity $\mathrm{HCO}_{3}^{-}$has been observed for carbonate minerals such as calcite [42]. The

147 expression for $k_{\text {calcite }}$ reads as follows

$k_{\text {calcite }}=k_{25}^{\text {calcite }} \cdot \exp \left[\frac{-E_{a}^{\text {calcite }}}{R}\left(\frac{1}{T}-\frac{1}{298.15}\right)\right]+k_{25}^{\mathrm{HCO}_{3}^{-}} \cdot \exp \left[\frac{-E_{a}^{H C O_{3}^{-}}}{R}\left(\frac{1}{T}-\frac{1}{298.15}\right)\right] \cdot\left(a_{\mathrm{HCO}_{3}^{-}}\right)^{n_{H C O}^{-}}$

149

Eq. (5)

150 where $\mathrm{E}_{\mathrm{a}}^{\mathrm{i}}$ and $a_{i}$ are the activation energy $\left(\mathrm{kJ} \mathrm{mol}^{-1}\right)$ and the activity, and $k_{25}{ }^{i}$ and $n_{i}$ are a

151 model parameters for the species considered, in this particular case the mineral considered

152 (calcite) and $\mathrm{HCO}_{3}{ }^{-}$. Table 1 shows the numerical values of parameters for the kinetic

153 model selected [42]. 


\begin{tabular}{lcr}
\hline Parameters & Units & Values \\
\hline$k_{25}^{\text {calcite }}$ & $\mathrm{mol} \mathrm{m}^{-2} \mathrm{~s}^{-1}$ & $1.8 \cdot 10^{-7}$ \\
$k_{25}^{\mathrm{HCO} \mathrm{O}_{3}^{-}}$ & $\mathrm{mol} \mathrm{m}^{-2} \mathrm{~s}^{-1}$ & $1.9 \cdot 10^{-3}$ \\
$E_{a}^{\text {calcite }}$ & $\mathrm{kJ} \mathrm{mol}^{-1}$ & 66 \\
$E_{a}^{\mathrm{HCO}_{3}^{-}}$ & $\mathrm{kJ} \mathrm{mol}^{-1}$ & 67 \\
$n_{\mathrm{HCO}_{3}^{-}}$ & - & 1.63 \\
$\theta$ & - & 0.5 \\
$\eta$ & - & 2 \\
$S_{\text {calcite }}$ & $\mathrm{m}^{2} \mathrm{~kg}_{\mathrm{H}_{2} \mathrm{O}}^{-1}$ & 1.54 \\
\hline
\end{tabular}

\section{NUMERICAL IMPLEMENTATION}

162 The M4EKR model was implemented in COMSOL Multiphysics [44], a partial

163 differential equation solver developed in a multiphysics environment. COMSOL uses the

164 finite element method with Lagrange multipliers. One of its most remarkable attributes is

165 its versatility, since the user has great freedom to define the system of equations required

166 to solve the selected case [45-47].

167 M4EKR solves transport problems coupled with chemical speciation using a monolithic

168 approach, without using any other external software. This strategy optimises the resources

169 and reduces the computational cost. This aspect is of high importance and provides a

170 novelty to this work because it is common to use operator-splitting procedures for solving

171 reactive transport problems [48-50]. Furthermore, the computational capacity of the

172 M4EKR module goes beyond this kind of codes since it also allows to solve

173 simultaneously the partial differential equations that define the transport and balance of

174 mass of water, mass of dissolved species and electric charge, (See Appendix A, Eqs. A.1,

175 A.9 and A.10 respectively), the ordinary differential equations used to solve the mass 
176 balance in electrolyte wells, (Eq. A.11) and the algebraic equations from the

177 stoichiometric approach used in the chemical speciation.

\section{4. SIMULATION OF THE EKR PROCESS}

\section{4.1. Modelled configuration}

\section{$180 \quad$ 4.1.1. Polluted Soil}

181 The electrokinetic remediation of a polluted soil with an organochlorine herbicide (20 $\mathrm{mg}$

182 of clopyralid $\mathrm{kg}_{\text {drysoil }}^{-1}$ ) was analysed. The selected soil is a calcareous soil, (calcite mass

183 fraction 10\%). Table 2 presents the textural and mineralogical properties of the modelled

184 soil. The soil parameters are show in Table 3. Bulk density and gravimetric water content

185 are representative of the natural state of this soil [30].

186 Table 2. Textural and mineralogical properties of the modelled soil.

\begin{tabular}{cc}
\hline \multicolumn{2}{c}{ Mineralogical Analysis } \\
\hline Mineral & \% \\
\hline Quartz & 9 \\
Feldspar & 12 \\
Calcite & 10 \\
Kaolinite & 23 \\
Smectite & 25 \\
Illite & 21 \\
\hline Textural Parameters \\
\hline Size fraction & \% \\
\hline Sand & 26.1 \\
Silt & 68.6 \\
Clay & 5.3 \\
\hline
\end{tabular}

187

188

189

190

191 
Table 3. Modelled soil parameters.

\begin{tabular}{cccc}
\hline Parameters & Description & Values & Units \\
\hline$\alpha_{\mathrm{VG}}$ & Parameter of the Van Genuchten[51] retention curve & 0.0147 & $\mathrm{kPa}^{-1}$ \\
$n_{\mathrm{VG}}$ & Parameter of the Van Genuchten[51] retention curve & 1.2593 & - \\
$m_{\mathrm{VG}}$ & Parameter of the Van Genuchten[51] retention curve & 0.2059 & - \\
$\phi$ & Porosity & 0.4681 & - \\
$K_{\mathrm{sat}}^{\mathrm{h}}$ & Saturated hydraulic permeability & $2.03 \times 10^{-10}$ & $\mathrm{~m} \mathrm{~s}^{-1}$ \\
$K_{\mathrm{sat}}^{\mathrm{e}}$ & Saturated electroosmotic permeability & $2.4 \times 10^{-9}$ & $\mathrm{~m}^{2} \mathrm{~V}^{-1} \mathrm{~s}^{-1}$ \\
$\rho_{s}$ & Soil particle density & 2681.5 & $\mathrm{~kg} \mathrm{~m}^{-3}$ \\
$\rho_{\text {bulk }}$ & Bulk density & 1894.4 & $\mathrm{~kg} \mathrm{~m}^{-3}$ \\
$w$ & Moisture & 0.32 & $\mathrm{~kg}_{\text {water }} \mathrm{kg}_{\mathrm{dry}}$ soil \\
$\delta_{\mathrm{i}}^{\mathrm{L}}$ & Longitudinal dispersivity of species $i$ & 0.01 & $\mathrm{~m}^{\mathrm{L}}$ \\
$\tau$ & Vapour tortuosity & 1.00 & - \\
\hline
\end{tabular}

193

194 4.1.2. Porewater

195 The geochemical model implemented consists of 7 components and 20 secondary species.

196 The chemical reactions and thermodynamic properties (equilibrium constants [43], hard-

197 core diameters and diffusion coefficients) are presented in Table 4. The activity

198 coefficients of the species were estimated by WATEQ Debye-Hückel model [52]. 
Table 4. Thermodynamic properties of the modelled geochemical systems

\begin{tabular}{|c|c|c|c|c|c|}
\hline & Species & Reactions & $\begin{array}{r}\log K_{\mathrm{i}}^{\mathrm{eq}} \\
\left(25^{\circ} \mathrm{C}\right)\end{array}$ & $\begin{array}{r}\text { Hard core } \\
\text { diameter } / \AA\end{array}$ & $D_{\mathbf{i}^{0}} / \mathrm{m}^{2} \mathbf{s}^{-1}$ \\
\hline \multirow{7}{*}{ Components } & $\mathrm{Cl}^{-}$ & $\mathrm{Cl}^{-}$ & 0 & 3.6 & $2.03 \times 10^{-9}$ \\
\hline & $\mathrm{H}_{2} \mathrm{O}$ & $\mathrm{H}_{2} \mathrm{O}$ & 0 & 3.4 & $5.27 \times 10^{-9}$ \\
\hline & $\mathrm{H}^{+}$ & $\mathrm{H}^{+}$ & 0 & 4.1 & $9.31 \times 10^{-9}$ \\
\hline & $\mathrm{CO}_{3}^{-2}$ & $\mathrm{CO}_{3}^{-2}$ & 0 & 4.7 & $9.55 \times 10^{-10}$ \\
\hline & $\mathrm{Ca}^{+2}$ & $\mathrm{Ca}^{+2}$ & 0 & 5.7 & $7.93 \times 10^{-10}$ \\
\hline & $\mathrm{Na}^{+}$ & $\mathrm{Na}^{+}$ & 0 & 4.1 & $1.33 \times 10^{-9}$ \\
\hline & Clopy ${ }^{-}$ & Clopy $^{-}$ & 0 & 3.6 & $8.20 \times 10^{-10^{*}}$ \\
\hline \multirow{13}{*}{$\begin{array}{l}\text { Secondary } \\
\text { species }\end{array}$} & $\mathrm{OH}^{-}$ & $\mathrm{H}_{2} \mathrm{O} \leftrightarrow \mathrm{OH}^{-}+\mathrm{H}^{+}$ & -14 & 3.6 & $5.27 \times 10^{-9}$ \\
\hline & $\mathrm{HCO}_{3}^{-}$ & $\mathrm{CO}_{3}^{-2}+\mathrm{H}^{+} \leftrightarrow \mathrm{HCO}_{3}^{-}$ & 10.33 & 3.6 & $1.18 \times 10^{-9}$ \\
\hline & $\mathrm{H}_{2} \mathrm{CO}_{3}$ & $\mathrm{CO}_{3}^{-2}+2 \mathrm{H}^{+} \leftrightarrow \mathrm{H}_{2} \mathrm{CO}_{3}$ & 16.68 & 3.4 & $1.92 \times 10^{-9}$ \\
\hline & $\mathrm{CaHCO}_{3}^{+}$ & $\mathrm{Ca}^{+2}+\mathrm{CO}_{3}^{-2}+\mathrm{H}^{+} \leftrightarrow \mathrm{CaHCO}_{3}{ }^{+}$ & 11.43 & 4.1 & $5.06 \times 10^{-10}$ \\
\hline & $\mathrm{CaCO}_{3}$ & $\mathrm{Ca}^{+2}+\mathrm{CO}_{3}^{-2} \leftrightarrow \mathrm{CaCO}_{3}$ & 3.22 & 3.4 & $4.46 \times 10^{-10}$ \\
\hline & $\mathrm{Ca}(\mathrm{OH})^{+}$ & $\mathrm{Ca}^{+2}+\mathrm{H}_{2} \mathrm{O} \leftrightarrow \mathrm{Ca}(\mathrm{OH})^{+}+\mathrm{H}^{+}$ & -12.78 & 4.1 & $2.13 \times 10^{-10^{*}}$ \\
\hline & $\mathrm{NaHCO}_{3}$ & $\mathrm{Na}^{+}+\mathrm{HCO}_{3}^{-} \leftrightarrow \mathrm{NaHCO}_{3}$ & 10.08 & 3.4 & $6.73 \times 10^{-10}$ \\
\hline & $\mathrm{NaCO}_{3}^{-}$ & $\mathrm{Na}^{+}+\mathrm{CO}_{3}^{-2} \leftrightarrow \mathrm{NaCO}_{3}^{-}$ & 1.27 & 3.6 & $5.85 \times 10^{-10}$ \\
\hline & $\mathrm{NaOH}$ & $\mathrm{Na}^{+}+\mathrm{H}_{2} \mathrm{O} \leftrightarrow \mathrm{NaOH}+\mathrm{H}^{+}$ & -14.75 & 3.4 & $1.89 \times 10^{-10^{*}}$ \\
\hline & $\mathrm{CaCl}^{+}$ & $\mathrm{Ca}^{+2}+\mathrm{Cl}^{-} \leftrightarrow \mathrm{CaCl}^{+}$ & -0.29 & 4.1 & $2.13 \times 10^{-10^{*}}$ \\
\hline & $\mathrm{NaCl}$ & $\mathrm{Na}^{+}+\mathrm{Cl}^{-} \leftrightarrow \mathrm{NaCl}$ & -0.5 & 3.4 & $1.89 \times 10^{-10^{*}}$ \\
\hline & $\mathrm{CaCl}_{2}$ & $\mathrm{Ca}^{+2}+2 \mathrm{Cl}^{-} \leftrightarrow \mathrm{CaCl}_{2}$ & -0.64 & 3.4 & $7.54 \times 10^{-10}$ \\
\hline & Clopy ${ }^{-}$ & Clopy $+\mathrm{H}^{+} \leftrightarrow$ Clopy & 2.32 & 3.4 & $8.20 \times 10^{-10^{*}}$ \\
\hline Solid species & Calcite & Calcite $\leftrightarrow \mathrm{Ca}^{+2}+\mathrm{CO}_{3}^{-2}$ & $-8.48^{* *}$ & & \\
\hline
\end{tabular}

* Obtained by using Pikal's model [53].

\subsubsection{Modelled Experimental setup}

209 The experimental setup modelled was a lab-scale EKR reactor. This setup is composed

210 of an electrokinetic cell divided in three compartments: the anolyte compartment(AC),

211 the catholyte compartment (CC), where electrodes are located and with dimensions

$21215 \times 3 \times 3 \mathrm{~cm}$, and a central compartment destined to place the polluted soil with a capacity

213 of $675 \mathrm{ml}$ (LWH: $15 \times 15 \times 3 \mathrm{~cm}$ ). The level of electrolyte in compartments is constant

214 during the tests by adding anolyte through gravity and extracting the catholyte by

215 overflow of the CC. This modelled experimental setup has been outlined in detail in 
216 preceding studies [26, 36, 37]. Fig. 1 shows a scheme of the conceptual model of the setup

217 simulated.

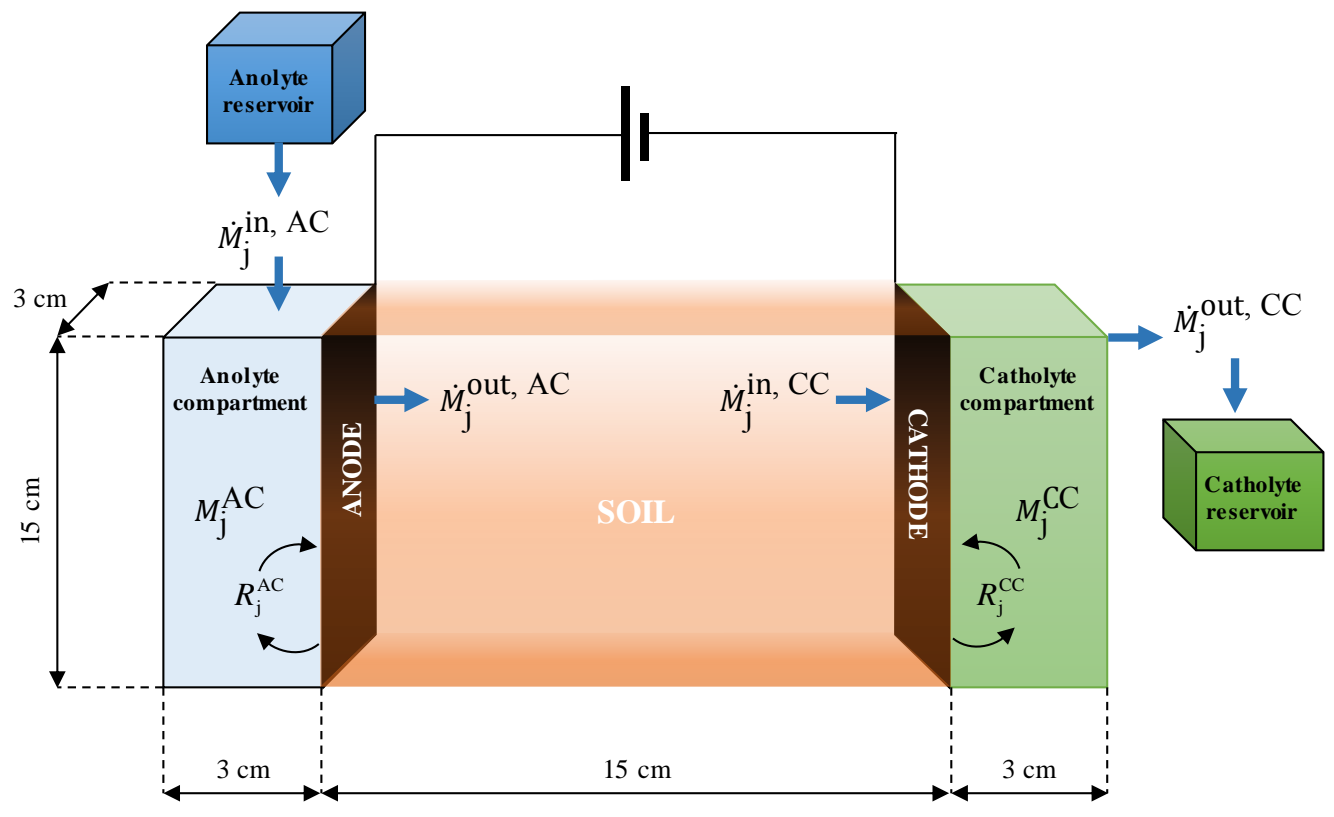

219 Figure 1. Conceptual model of the one-dimensional domain proposed for simulation. Symbols 220 described in Appendix A.

221 This setup defines a one-dimensional (1D) configuration that allows reducing the 222 computational time and provides easily interpretable results needed to understand the 223 EKR main trends.

\subsubsection{Initial conditions}

225 The initial mass fraction of calcite in the soil was $10 \%$. The initial electrolytes (anolyte and catholyte) are an aqueous solution of $\mathrm{CaCO}_{3}$ and $\mathrm{NaCl}$ equilibrated with the calcite present in the soil. The same solution with an amount of clopyralid equivalent to $20 \mathrm{mg}$

$228 \mathrm{~kg}_{\text {dry soil }}^{-1}$ is considered as initial porewater. The electrolyte added to the AC during the 229 EKR test is an aqueous $\mathrm{NaCl}$ solution with the same $\mathrm{pH}$ as the initial porewater. Table 5 230 shows the chemical initial conditions of the different solutions used in the study. 


\begin{tabular}{|c|c|c|c|c|c|c|c|c|}
\hline & \multicolumn{6}{|c|}{ Total components concentration / m } & \multirow{2}{*}{ pH } & \multirow{2}{*}{$\begin{array}{c}\text { Ionic } \\
\text { Strength } \\
\text { / m }\end{array}$} \\
\hline & $\mathbf{H}^{+}$ & $\mathrm{Na}^{+}$ & $\mathrm{Ca}^{2+}$ & $\mathrm{CO}_{3}{ }^{2-}$ & $\mathrm{Cl}^{-}$ & Clopyanion & & \\
\hline $\begin{array}{l}\text { Soil } \\
\text { porewater }\end{array}$ & $3.41 \times 10^{-3}$ & $3.58 \times 10^{-3}$ & $2.49 \times 10^{-3}$ & $3.12 \times 10^{-3}$ & $5.36 \times 10^{-3}$ & $3.67 \times 10^{-4}$ & 7.25 & $1.10 \times 10^{-2}$ \\
\hline $\begin{array}{l}\text { Inital } \\
\text { electrolyte }\end{array}$ & $3.41 \times 10^{-3}$ & $3.58 \times 10^{-3}$ & $2.49 \times 10^{-3}$ & $3.12 \times 10^{-3}$ & $5.75 \times 10^{-3}$ & 0 & 7.25 & $1.10 \times 10^{-2}$ \\
\hline $\begin{array}{l}\text { Addition to } \\
\text { anolyte } \\
\text { reservoir }\end{array}$ & $-1.32 \times 10^{-7}$ & $3.58 \times 10^{-3}$ & 0 & 0 & $3.57 \times 10^{-3}$ & 0 & 7.25 & $3.57 \times 10^{-3}$ \\
\hline
\end{tabular}

233

234 Initially, the electrolyte compartments are filled completely and they are open to 235 atmosphere, therefore the initial liquid pressure, $P_{\mathrm{L}}$, is equal to $100 \mathrm{kPa}$ (atmosphere 236 pressure). The initial condition was an electric potential gradient equal to zero.

\subsubsection{Boundary conditions}

238 To solve the problem presented in this work it is necessary to define three types of 239 boundary conditions for each of the balances presented: electrical, hydraulic and mass of 240 dissolved chemical species. For the first case, an average electrical potential gradient of

$2411 \mathrm{~V} \mathrm{~cm}^{-1}$ was applied. In the case of water mass balance, the boundary condition with the 242 initial condition $\left(P_{\mathrm{L}}=100 \mathrm{kPa}\right)$ since the compartments are open to the atmosphere and 243 maintain a constant level during all the cases evaluated. The boundary condition used in 244 the mass balances of chemical species was imposed by the concentration of components 245 in the electrolyte compartments. It is important to note that the definition of this type of 246 boundary condition is obtained in a coupled form by means of the resolution of J-2 247 ordinary differential equations defining the mass balance of the chemical components in 248 the electrolyte wells. (See Appendix A, Eq. A.11). 


\subsection{Simulation of EKR tests}

251 3.2.1. Effect of calcite dissolution-precipitation process in EKR behaviour.

252 In this section, the importance of calcite dissolution-precipitation processes in the 253 performance of an EKR process has been evaluated. To this end, two EKR processes have 254 been studied: (i) the treatment of the described soil contaminated with clopyralid, in 255 which the dissolution-precipitation processes of this mineral have been taken into account 256 (Mineral Reaction test, MR-test) and (ii) an EKR process equivalent to the first case, in 257 which it has been assumed that there are no precipitation-dissolution processes of calcite 258 (no Mineral Reaction test, nMR-test). This strategy has been selected to determine the 259 effect of these reactions on the overall performance and behaviour of the selected EKR 260 process.

261 Figure 2 shows the spatial distribution of the $\mathrm{pH}$ in both tests for different observation 262 times $(0,1,2,24$ and $48 \mathrm{~h})$.

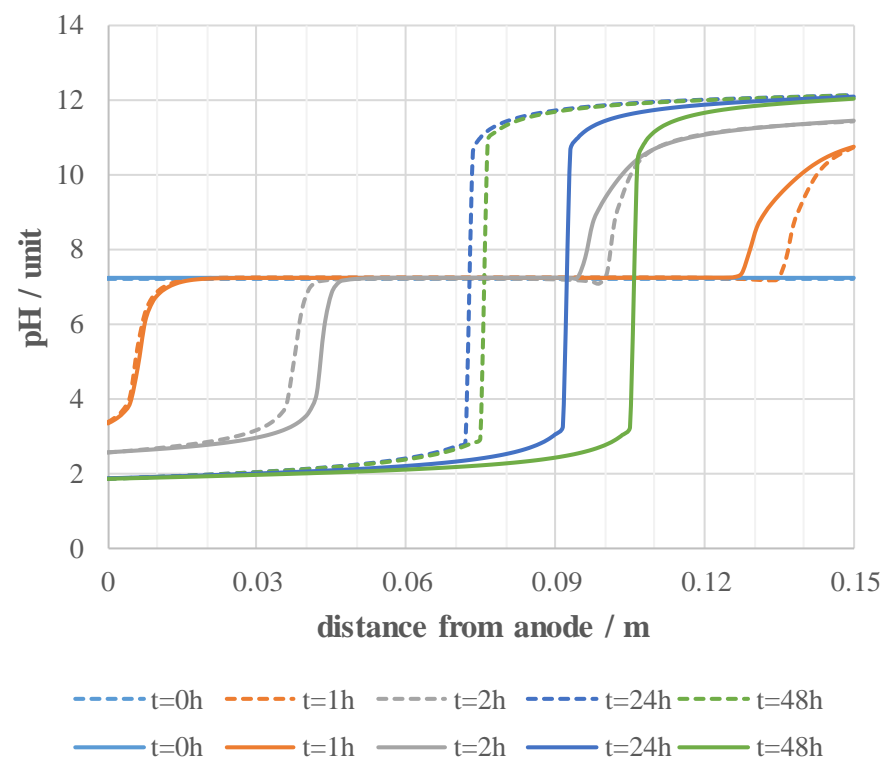

264 Figure 2. pH spatial distribution at selected times. MR-test, dashed line; nMR-test, solid line. 
265 In both tests, the $\mathrm{pH}$ distribution observed in the domain is characteristic of EKR treated

266 soil. At short times $(1 \mathrm{~h})$, the generation of a $\mathrm{pH}$ gradient between the anodic $(\mathrm{pH}=3.5)$

267 and cathodic $(\mathrm{pH}=10.5)$ zones due to the generation of $\mathrm{H}^{+}$in the $\mathrm{AC}$ and $\mathrm{OH}^{-}$in the $\mathrm{CC}$

268 through the electrolysis of water is already observed. The transport of these ionic species

269 through the soil generates an acidic $\mathrm{pH}$ front (to the cathode) and an alkaline $\mathrm{pH}$ front (to

270 the anode) that collide at a point where the $\mathrm{pH}$ gradient is maximum. The location of this

271 point will be very important in the discussion of results, the Maximum pH Gradient Point

272 (MpHGP). It can be seen how the velocity with which the $\mathrm{pH}$ fronts move is different in

273 the two numerical tests evaluated. The rate of advance of the acidic front is slower in the

274 case of MR-test. This decrease is more significant at higher test times. It can be seen that

275 after 48 hours of testing the acidic front has spread over $10.5 \mathrm{~cm}$ of the domain in the

276 nMR-test, and only $7.5 \mathrm{~cm}$ in the MR-test. This behaviour suggests that the MR-test

277 involves additional processes that act as a $\mathrm{pH}$ buffer such as the dissolution of calcite

278 [54]. The spatial distribution of the calcite content in the MR-test is shown in Fig. 3. It is

279 important to note that initially the calcite content is in equilibrium with the calcium

280 carbonate concentration. 

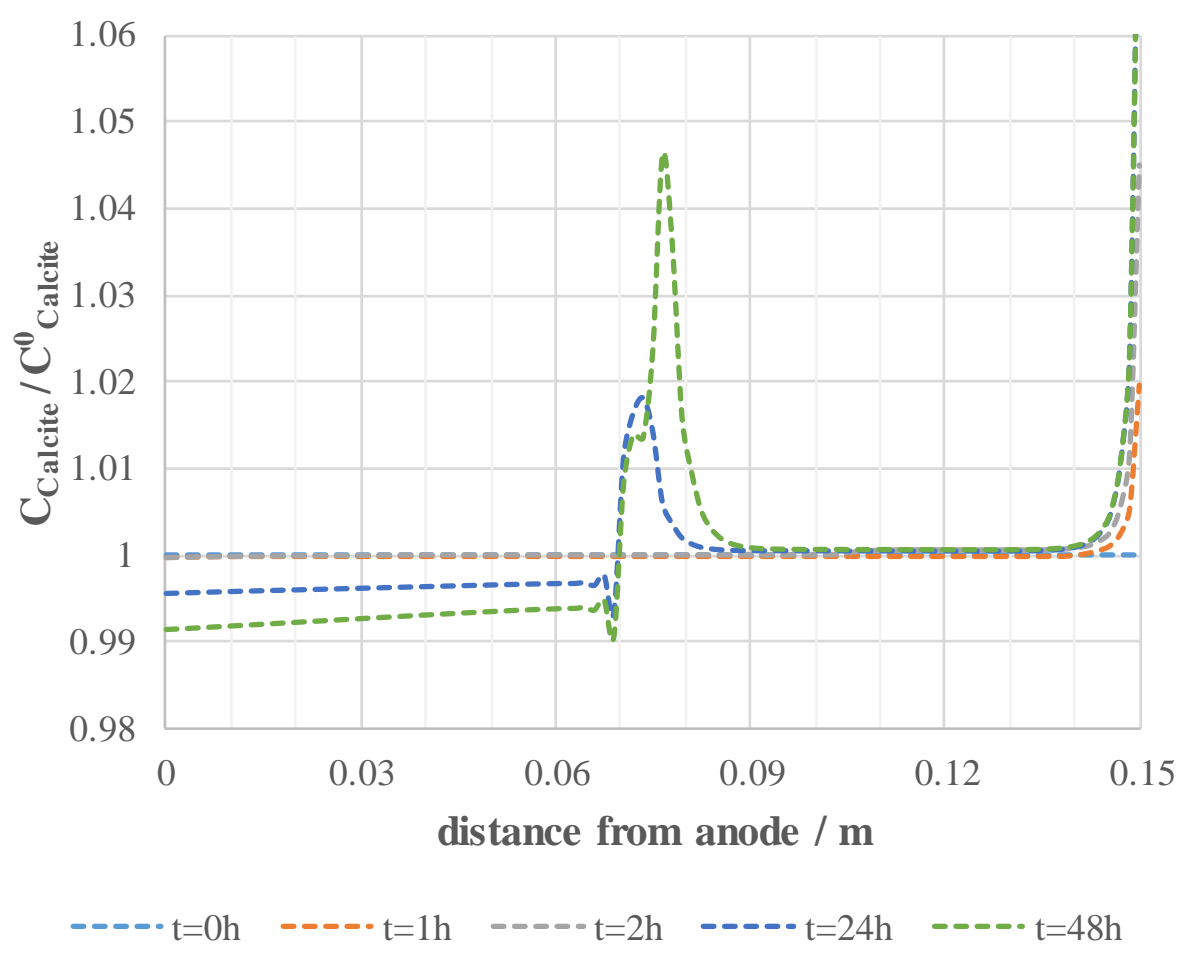

Figure 3. Spatial distribution of normalized calcite content at selected times in MR-test.

283 On the other hand, when the content of calcite in the soil is analysed, three areas with 284 different behaviour can be identified. In the zone with acidic $\mathrm{pH}$, between $\mathrm{AC}$ and 285 MpHGP, a decrease in the initial calcite content of the soil is observed, accentuating in 286 the zone immediately adjacent to MpHGP. The calcite dissolution process is active under 287 these conditions, and this trend is most noticeable at higher test times (24 and $48 \mathrm{~h}$ ) 288 because these processes have been simulated by means of a chemical kinetic process and 289 not by a chemical equilibrium. Meanwhile, in the soil-CC interface zone (where the 290 cathode is located) a sudden increase in the calcite content generated by the precipitation 291 can be seen. This behaviour has been observed (Fig. 4) in previous experimental work $292[55]$. 

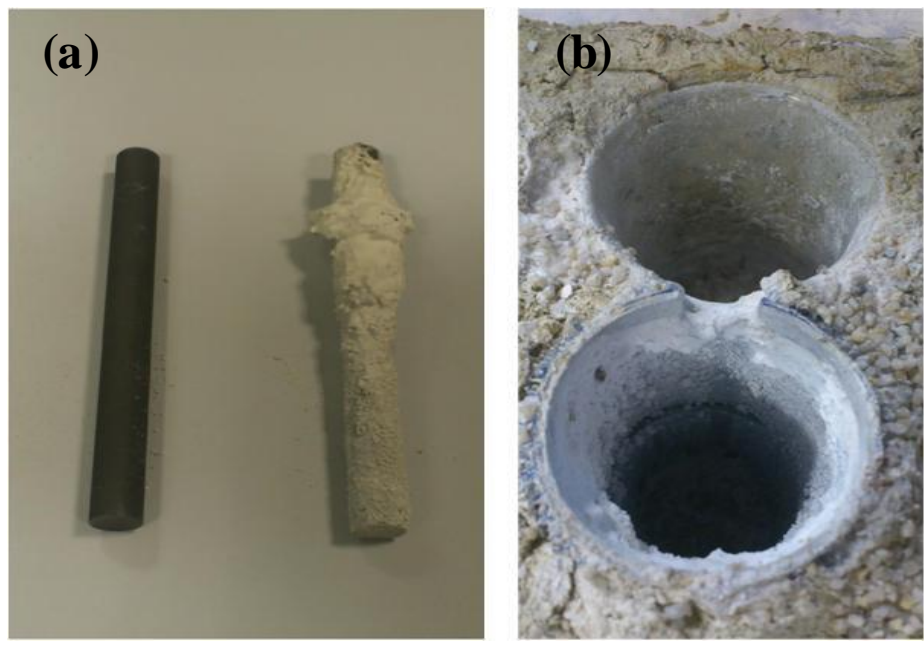

Figure 4. Evidences of mineral precipitation on (a) cathode before EKR and (b) CC.

295 The third zone which was identified corresponds to the domain close to the MpHGP

296 where the acidic and alkaline $\mathrm{pH}$ fronts (maximum $\mathrm{pH}$ gradient) are located. In this area

297 there is an accumulation of calcite. In both the second and third zones, the observed

298 calcite precipitation is limited only to very localize areas and not to the entire soil domain

299 with basic $\mathrm{pH}$, as would be expected. In order to understand more precisely the processes

300 of calcite dissolution-precipitation observed in Figure 3, it is necessary to analyze the

301 chemical speciation of the carbonate system. For this purpose, the spatial distribution of

302 the concentration of the carbonate species $\left(\mathrm{H}_{2} \mathrm{CO}_{3}^{\circ}, \mathrm{HCO}_{3}^{-}, \mathrm{CO}_{3}^{-2} \mathrm{y} \mathrm{Ca}^{2+}\right)$ is shown in Fig.

3035 

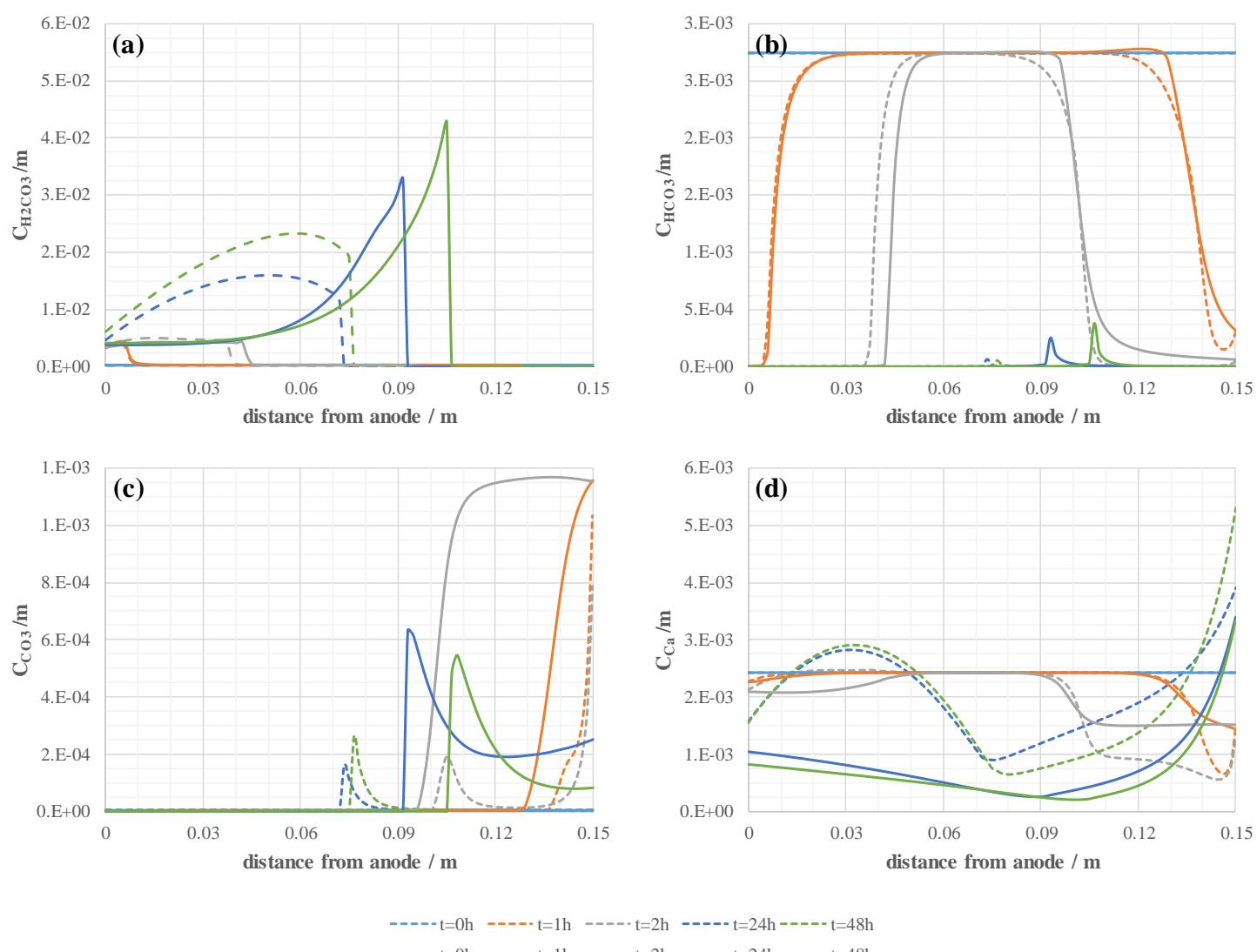

306 Figure 5. Spatial distribution of species concentration at selected times. MR-test, dashed line; nMR-test, solid line. (a) $\mathrm{H}_{2} \mathrm{CO}_{3}^{\circ}$, (b) $\mathrm{HCO}_{3}^{-}$, (c) $\mathrm{CO}_{3}^{-2}$ and (d) $\mathrm{Ca}^{2+}$.

308 Fig. 5a shows the distribution of $\mathrm{H}_{2} \mathrm{CO}_{3}^{\circ}$ (species including the sum of the concentrations of $\mathrm{H}_{2} \mathrm{CO}_{3}$ and dissolved $\mathrm{CO}_{2}$ ) in the domain. A common trend is observed in both numerical tests, the accumulation of this species in the post-MpHGP area. This can be

311 explained taking into account that this species is only present in systems with $\mathrm{pH}$ highly

312 acid. In addition, taking into account the transport features, this species has a neutral

313 charge, so the predominant transport mechanisms are the advective flux (hydraulic and 314 electro-osmotic flow) and the diffusive/dispersive processes with a net flux from anode 315 to cathode [26]. However, if we compare the spatial distributions at the same observation

316 times, we can see how there are notable differences between the two tests analysed. In

317 the MR-test it is observed the $\mathrm{H}_{2} \mathrm{CO}_{3}^{\circ}$ is present in a smaller volume of soil, which 318 indicates that there is a relationship between the concentration of $\mathrm{H}_{2} \mathrm{CO}_{3}^{\circ}$ and the process 
319 of dissolution of calcite. As Plummer demonstrated [39], this process takes place through

320 simultaneous reactions (See Eq.5-9).

$321 \mathrm{CaCO}_{3}+\mathrm{H}^{+} \leftrightharpoons \mathrm{Ca}^{2+}+\mathrm{HCO}_{3}^{-}$

$322 \mathrm{CO}_{3}^{2-}+2 \mathrm{H}^{+} \leftrightharpoons \mathrm{H}_{2} \mathrm{CO}_{3}^{\circ}$

$323 \mathrm{CaCO}_{3}+\mathrm{H}_{2} \mathrm{CO}_{3}^{\circ} \leftrightharpoons \mathrm{Ca}^{2+}+2 \mathrm{HCO}_{3}^{-}$

$\mathrm{CaCO}_{3}+\mathrm{H}_{2} \mathrm{O} \leftrightharpoons \mathrm{Ca}^{2+}+\mathrm{HCO}_{3}^{-}+\mathrm{OH}^{-} \leftrightharpoons \mathrm{Ca}^{2+}+\mathrm{CO}_{3}^{-}+\mathrm{H}_{2} \mathrm{O}$

325 The progression of these reactions depends directly on the $\mathrm{pH}$ of the system and therefore 326 on the chemical speciation of the carbonate system. [56]. In systems with strongly acidic 327 pHs, the Eq.6 and Eq.7 reactions become important. Taking into account this reactivity, the consumption of $\mathrm{H}^{+}$produced by the water electrolysis could justify the slowing down observed in the MR-test of the acidic front (See Fig. 2), the reduction of the calcite content

330 by dissolution (See Fig. 3) and the increase in the concentration of $\mathrm{H}_{2} \mathrm{CO}_{3}$ and 331 accumulation in the area after the acidic front (See Fig. 5a). In addition, the decrease of 332 the calcite content in the left side of the MpHGP point could be explained if it is known that the predominant reaction of the calcite solution is the Eq. 6 reaction and if it is taken

334 into account that for $\mathrm{pH}$ greater than 5 and with a partial pressure of $\mathrm{CO} 2$ greater than 0.1

335 atm, Eq. 8 becomes important. With the contribution of the latter reaction to the general 336 process of dissolution, the change in shape of the spatial distribution of $\mathrm{H}_{2} \mathrm{CO}_{3}$ mentioned 337 above can be satisfactorily described.

338 The second carbonate species analysed was the bicarbonate ion, $\mathrm{HCO}_{3}^{-}$(Fig. 5b). This 339 species exists at $\mathrm{pH}$ values between 6.3 and 10.25 . For this reason, $\mathrm{HCO}_{3}^{-}$is present in 340 significant amounts only in the initial stage of the test $(1$ and $2 \mathrm{~h})$, when the $\mathrm{pH}$ fronts are 341 not very abrupt. The ion carbonate, $\mathrm{CO}_{3}^{-2}$, exhibits the opposite behavior to $\mathrm{H}_{2} \mathrm{CO}_{3}^{\circ}$. The 
$342 \mathrm{CO}_{3}^{-2}$ is predominantly presents in the right side of the MpHGP and has negative charge

343 as well as $\mathrm{HCO}_{3}^{-}$. Both species are predominantly transported by electromigration to the

344 anode. These clarifications could explain the spatial distribution of the concentration of

345 these species and the accumulation observed behind the MpHGP (See Fig. 5b and 5c).

346 Quantitatively, the MR-test presents a lower accumulation of both $\mathrm{CO}_{3}^{-2}$ and $\mathrm{HCO}_{3}^{-}$in the

347 area near the MpHGP since these species are, together with $\mathrm{Ca}^{2+}$ (See reaction R.9), the

348 drivers of the generation of calcite by precipitation (See Fig.3). This behaviour is also

349 observed in the area of the soil-CC interface, even at short test times ( 1 and $2 \mathrm{~h}$ ). This

350 suggests that the precipitation process is faster than the dissolution process, as there is no

351 decrease in calcite content at those times. In order to check this fact, the dimensionless

352 reaction rate $R_{\text {calcite }}^{*}$ has been evaluated as a function of the saturation ratio, $\Omega_{\text {calcite }}$ using

353 the expression (10) and giving the results in Figure 6.

354

$R_{\text {calcite }}^{*}=\cdot\left(1-\Omega_{\text {calcite }}^{\theta}\right)^{\eta}$

Eq. (10)

and giving the results in Figure 6.

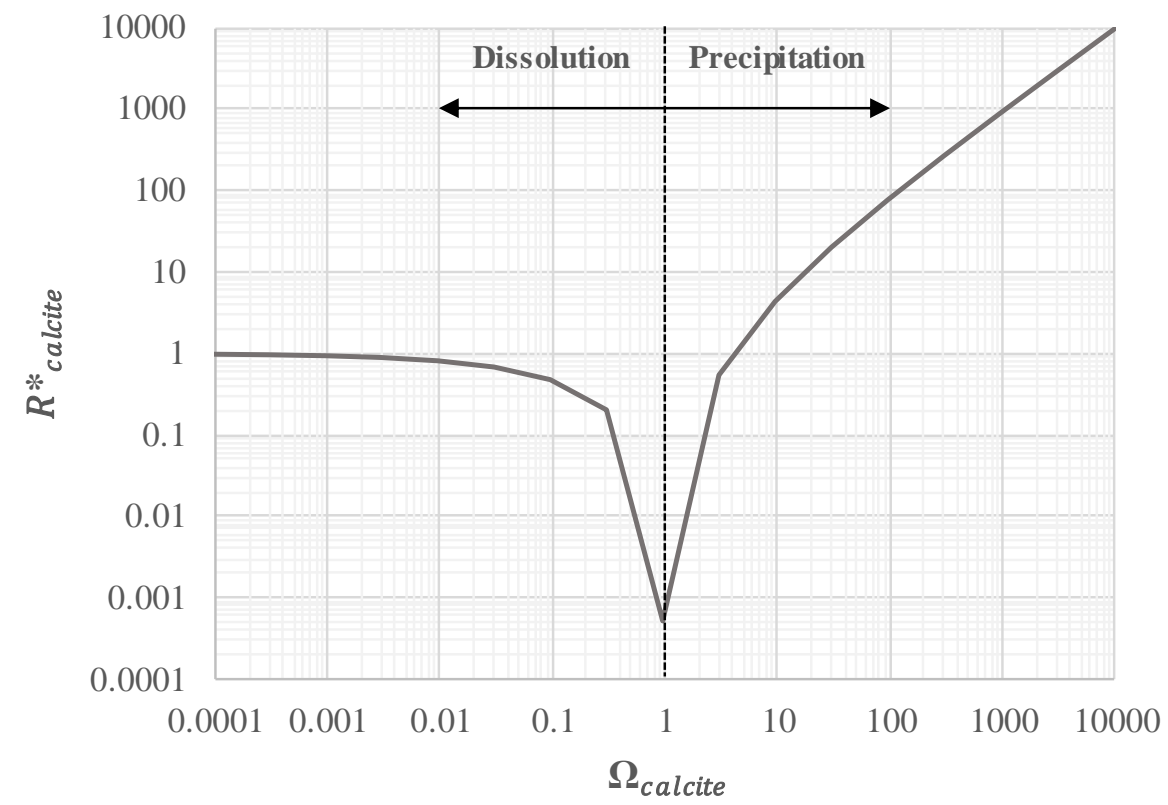

357 Figure 6. Influence of saturation ratio in dimensionless reaction rate. 
358 Starting from a system in equilibrium $\left(\Omega_{\text {calcite }}=1\right)$, it can be observed that a decrease of $359 \Omega_{\text {calcite }}$ activates the process of dissolution of calcite. The rate of the calcite dissolution

360 process has an increasing trend corresponding to the decrease of the $\Omega_{\text {calcite }}$. This 361 evolution continues until it reaches a point where the reaction rate is stabilized at a 362 constant value. This implies that from this point on, the dependence of the reaction rate 363 of the dissolution process with $\Omega_{\text {calcite }}$. is negligible. Meanwhile, the precipitation 364 process occurs when $\Omega_{\text {calcite }}$ is greater than 1 . The evolution of the precipitation reaction 365 rate as a function of $\Omega_{\text {calcite }}$ is entirely different. A roughly double log-linear increase is 366 observed with the increase in the saturation ratio. This indicates that the precipitation rate 367 is proportional to the concentration of species involved in that reaction (See reaction 368 Eq.8). In this line, from a quantitative point of view, it can be observed how changes in 369 an order of magnitude in $\Omega_{\text {calcite }}$ are translated into much more significant changes in 370 the reaction rate in the precipitation process. This would explain the rapid calcite 371 deposition shown in Fig. 3. Finally, the spatial distribution of $\mathrm{Ca}^{2+}$ ion is analysed (Fig.

$3725 \mathrm{~d})$. Both tests show an accumulation of this species in the area of the $\mathrm{CC}$, mainly due to 373 the contribution of the electromigration process to the net transport of this ion [26]. The 374 most noticeable difference between the two tests analysed is the increase in concentration 375 observed in the acidic zone (after MpHGP) in the MR-test. This trend is according with 376 the process of calcite dissolution observed in this zone.

377 Subsequently, the influence of the buffer effect generated by the dissolution of calcite on 378 the speciation and transport of clopyralid was analysed. Two species have been 379 considered, acid and anionic. 

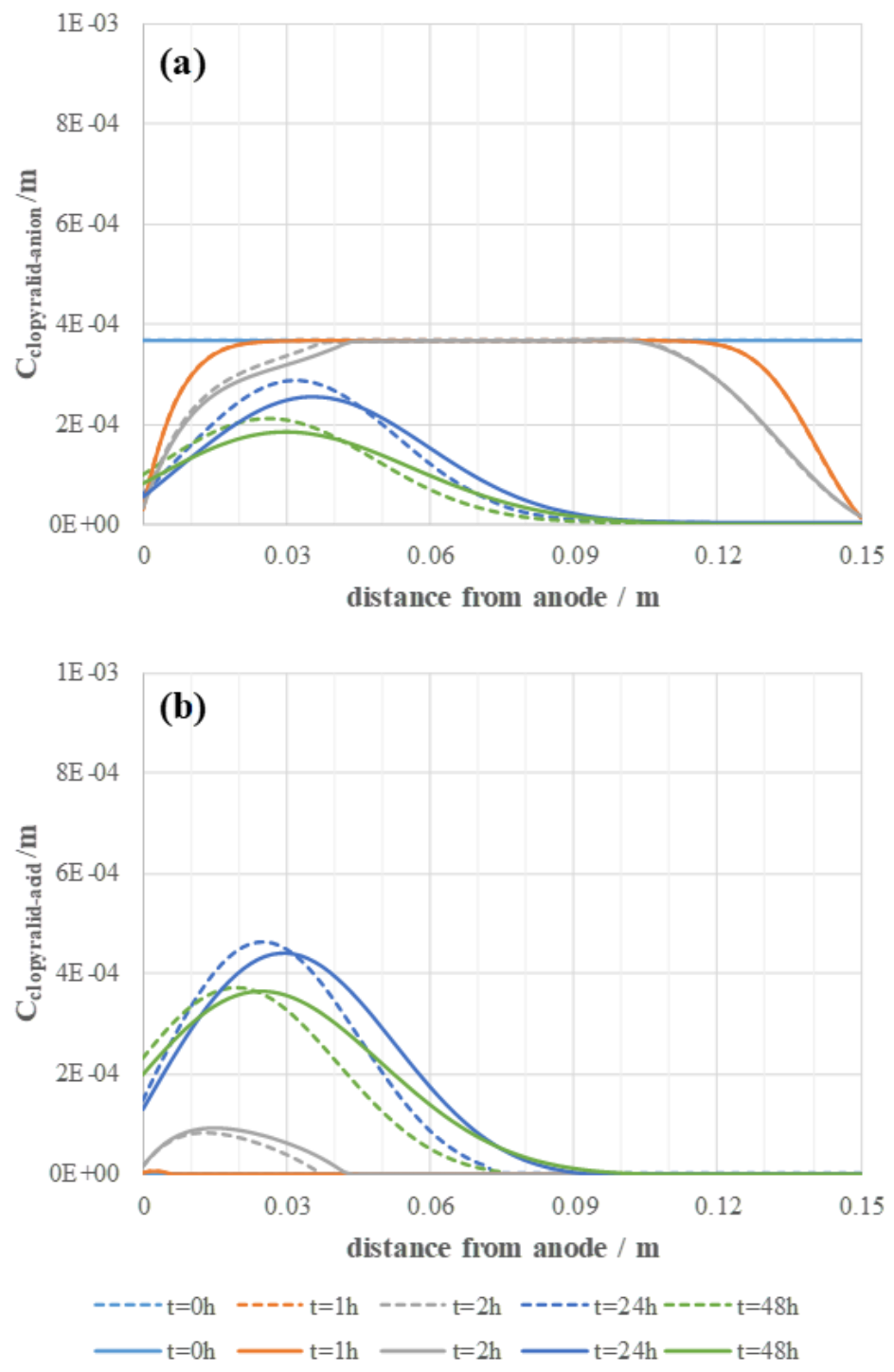

382 Figure 7. Spatial distribution of the total concentration of (a) Clopyralid ${ }_{\text {anion }}$ species and (b)

383 Clopyralid ${ }_{\text {acid }}$ species at selected times. MR-test, dashed line; nMR-test, solid line.

385 The $\mathrm{pH}$ of the soil pore water affects the chemical speciation of the substances contained

386 in the soil $[22,57]$, so acidic species are present in the low $\mathrm{pH}$ soil zone, generally between

387 CA and MpHGP in EKR processes. In the case studied, Clopyralidacid species are 388 concentrated in this zone, favouring the transport of these species to the anodic 389 compartment mainly by diffusion [36]. Furthermore, Clopyralid ${ }_{\text {anion }}$ species, in 390 equilibrium with acidic species, also accumulate in this zone and is susceptible to being 
moved towards the anodic compartment mainly by electromigration [36]. For these

392 reasons, the performance of the EKR treatment of soils with this type of pollutant (acid

393 pollutant with anionic dissociation) improves when the volume of the acid soil zone is

394 reduced as has been proven in previous works [36]. The buffer effect generated by the

395 dissolution of calcite produces a reduction of the acidic zone. This is how it can be seen

396 in Fig 7. Fig 7 shows in those locations where an accumulation of contaminant is observed

397 (in one of the two species considered) it is always shown to a lesser extent in the MR398 test.

399 3.2.2. Sensitivity analysis of reactive surface area in EKR behaviour.

400 The buffer capacity of the soil depends directly on the precipitation/dissolution kinetics

401 of calcite, however, as previously discussed in the introduction, it is considerably

402 complex to accurately to estimate the kinetics due to the high uncertainty associated with

403 the reactive surface area [39]. For this reason, a sensitivity analysis of the simulated EKR

404 process has been carried out for different values of this parameter. For this purpose, three

405 additional MR-tests have been simulated in which a reactive surface area $\left(S_{\text {calcite }}\right)$ value

406 of $3.08,10$ y $100 \mathrm{~m}^{2} \mathrm{~kg}_{\mathrm{H}_{2} \mathrm{O}}^{-1}$ (compared to the 1.54 used in the case analysed in section

407 3.2.1), has been assumed. The main results obtained in this study are shown in Fig. 8. 

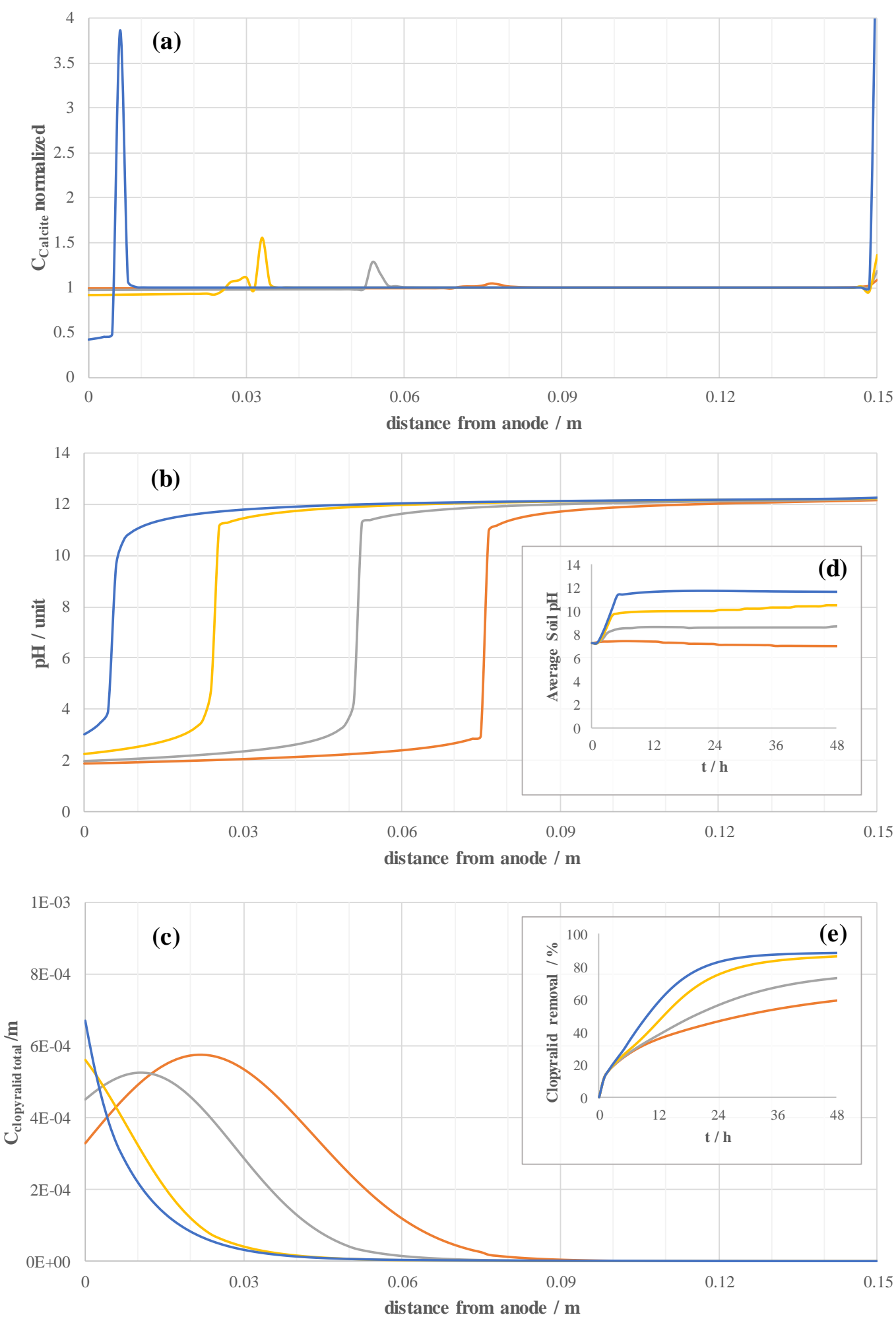

- Scalcite $=1.54-$ Scalcite $=3.08-$ Scalcite $=10-$ Scalcite $=100$

409 Figure 8. Sensitivity analysis of reactive surface area. Spatial distribution of the (a) of normalized

410 calcite content, (b) $\mathrm{pH}$ and (c) total concentration of Clopyralid species in soil at time test of 48

411 h. Dynamic response of the (d) average soil pH and (e) Clopyralid removal. 
412 From a kinetic point of view, an increase in the value of $S_{\text {calcite }}$ translates into an increase

413 in the rate at which the dissolution and precipitation processes of calcite take place.

414 However, qualitatively, no significant influence is found. This can be verified by

415 analysing Fig. 8a. The behaviour observed in the cases studied is common; the same three

416 previously identified areas with active calcite reactivity are shown (Fig.3): (i) generalised

417 dissolution in the acidic zone and punctual precipitation close to (ii) MpHGP and (iii)

418 cathode. The extent to which these reactions develop is directly related to the $S_{\text {calcite }}$ value 419 used.

420 Additionally, if the calcite dissolution process is specifically analyzed for a value of $S_{\text {calcite }}$ $421=100$, a decrease in the mineral content of the soil is observed and therefore the consumption of $\mathrm{H}^{+}$is more pronounced This statement is in accordance with the $\mathrm{pH}$ 423 profiles obtained in the MR-tests (Fig 8.b). It can be seen that as $S_{\text {calcite, }}$ increases, and therefore the kinetics of calcite dissolution, the speed of the acidic front slows down. In order to be able to evaluate the buffer capacity of the soil in global terms, the temporal evolution of the average $\mathrm{pH}$ has been analysed (Fig. 8d). The results obtained confirm that an increase in $S_{\text {calcite }}$ causes a significant improvement in soil buffer capacity. In the MR-test with $S_{\text {calcite }}=100$ an average $\mathrm{pH}$ value of 11.6 is obtained in $5 \mathrm{~h}$ of test, which means that in this case the acidic front is totally neutralized.

430 As discussed in the previous section, the $\mathrm{pH}$ of the porewater determines chemical 431 speciation and, consequently, the distribution of chemical species within the soil. 432 Therefore, the spatial distribution of the pollutant has been analysed (Fig. 8c). The 433 neutralization of the acidic front favours the accumulation of the contaminant in the area 434 close to the CA and therefore the transport to this compartment. An increase in the soil 435 buffer capacity produces an improvement in the performance of the EKR process, 436 reaching an elimination rate of close to $90 \%$ (Fig. 8e). Although these results cannot be 
437 taken valid in any configuration and for any soil, the information obtained in this 438 sensitivity study is valid to show how the soil buffer capacity strongly influences the net 439 performance of an EKR treatment.

\section{4. CONCLUSIONS}

441 This paper presents a numerical study of the processes of dissolution-precipitation of 442 calcite in soil contaminated with clopyralid (an herbicide of the organochlorine acid type) 443 by using an EKR treatment. The influence of the soil buffer capacity (associated with the 444 dissolution of calcite) on the overall performance of the remediation process is also 445 studied. In addition, experimentally observed behaviours, such as rapid calcite 446 precipitation in the cathode electrode and the compartment where it is located, have been 447 identified in the simulations. Thanks to the speciation of the carbonate system, it has been 448 possible to improve the relative understanding of the reactive transport of these chemical 449 species.

450 In addition, the results obtained have highlighted the importance of considering the 451 processes of dissolution-precipitation in an EKR treatment, since the distribution of the 452 soil $\mathrm{pH}$ depends to a large extent on them. The $\mathrm{pH}$ of the soil porewater is a fundamental 453 variable in EKR treatments as it directly influences the speciation of the contaminants 454 (and other chemical species present) and indirectly determines the transport mechanisms involved in the elimination of these contaminants. In the cases evaluated, it has been proven that the buffer effect produces improvements in the overall performance of the EKR process. The reduction of the advance of the acidic front, it favours the accumulation of polluting species in the vicinity of the anodic compartment and can be eliminated by means of anionic species by electromigration and of the acidic species by diffusive flux. 
460 All these conclusions have been confirmed after a sensitivity analysis in which it has been

461 evaluated how changes in the kinetics of the calcite dissolution-precipitation process

462 abruptly modify the buffer capacity of the soil and therefore strongly influence the

463 performance of the treatment. Therefore, it is very important to define accurately the

464 kinetic parameters (specifically, the reactive surface area) since the interpretation of the

465 results as well as the previous design of experimental setups depends on their numerical 466 values.

\section{ACKNOWLEDGEMENTS}

468 The authors acknowledge funding support from: (i) Ministerio de Economía, Industria y

469 Competitividad from Spanish Goverment and the European Union through the project 470 [CTM2016-76197-R (AEI/FEDER, UE)]; (ii) Junta de Comunidades de Castilla-La 471 Mancha and the European Union through the project [SBPLY/17/180501/000488 472 (JCCM/FEDER, UE)] and Postdoctoral Grant [SBPLY/16/180501/000402] awarded to 473 Dr. López-Vizcaíno; (iii) Conselho Nacional de Desenvolvimento Científico e 474 Tecnológico through the projects [CNPq-430121/2016-4], [CNPq-465571/2014-0], 475 [CNPq-446846/2014-7] and [CNPq-401519/2014-7]; and (iv) Fundação de Amparo à 476 Pesquisa do Estado de São Paulo through the project [2014/50945-4]. 


\section{A.1. Water mass balance}

482 Eq. (A.1) show the expression that defines the water mass balance:

$483 \quad \frac{\partial m_{\mathrm{w}}}{\partial t}+\nabla \cdot \mathbf{1}_{\mathrm{w}}=0$

484 where $m_{\mathrm{w}}$ is the mass of water per unit total volume $\left(\mathrm{kg} \mathrm{m}^{-3}\right)$, and it is defined as Eq (A.2),

$485 \nabla \cdot$ is the divergence operator, and $\mathbf{l}_{\mathrm{w}}$ is the mass flux of water $\left(\mathrm{kg} \mathrm{m}^{-2} \mathrm{~s}^{-1}\right)$.

486

$m_{\mathrm{w}}=\phi \cdot S r \cdot \rho_{\mathrm{w}}+\phi \cdot(1-S r) \cdot \rho_{v}$

Eq. (A.2)

487 where $\phi$ is the soil porosity, $S r$ is the degree of saturation of the soil defined by van 488 Genuchten model [58], $\rho_{\mathrm{w}}$ and $\rho_{\mathrm{v}}$ are the liquid and vapour water density $\left(\mathrm{kg} \mathrm{m}^{-3}\right)$ 489 respectively. Vapour water density is estimated using the psychrometric equation, Eq 490 (A.3) [59]:

491

$\rho_{\mathrm{v}}=\rho_{\mathrm{v}}^{\mathrm{o}} \cdot \exp \left(\frac{M_{\mathrm{W}} \cdot s}{\rho_{\mathrm{w}} \cdot R \cdot T}\right)$

492 where $M_{\mathrm{w}}$ is the water molar mass, $\mathrm{T}$ is absolute temperature and, $s$ is the matric suction, 493 assumed equal to the capillary one (osmotic suction is not considered).

494 Eq. (A.4) shows the expression to calculate the flux term $\mathbf{l}_{\mathrm{w}}$ :

$495 \quad \mathbf{l}_{\mathrm{w}}=\mathbf{l}_{\mathrm{w}}^{\mathrm{h}}+\mathbf{l}_{\mathrm{w}}^{\mathrm{eo}}=\rho_{\mathrm{w}} \cdot\left(\mathbf{q}_{\mathrm{w}}^{\mathrm{h}}+\mathbf{q}_{\mathrm{w}}^{\mathrm{eo}}\right)=\rho_{\mathrm{w}} \cdot \mathbf{q}_{\mathrm{w}}$ Eq. (A.4)

496 Where $\mathbf{l}_{\mathrm{w}}^{\mathrm{h}}$ is the Darcian flux, and $\mathrm{l}_{\mathrm{w}}^{\mathrm{e} 0}$ is the electroosmotic flux, estimated with the semi497 empirical model of Helmholtz-Smoluchowski [60]. The hydraulic and electroosmotic 498 volumetric fluxes are presented as $\mathbf{q}_{\mathrm{w}}^{\mathrm{h}}$ and $\mathbf{q}_{\mathrm{w}}^{\mathrm{eo}}$ (See Eq. (A.5) and (A.7) respectively). 499 $\mathbf{q}_{\mathrm{w}}^{\mathrm{h}}=-K_{\mathrm{e}}^{\mathrm{h}} \cdot\left(\nabla P_{\mathrm{L}}+g \cdot \rho_{\mathrm{w}} \cdot \nabla z\right)$ Eq. (A.5) 
$500 \quad K_{\mathrm{e}}^{\mathrm{h}}=K_{\mathrm{sat}}^{\mathrm{h}} \cdot k_{\mathrm{rel}}=K_{\mathrm{sat}}^{\mathrm{h}} \cdot S r^{3}$

Eq. (A.6)

$501 \quad \mathbf{q}_{\mathrm{w}}^{\mathrm{eo}}=-K_{\mathrm{e}}^{\mathrm{eo}} \cdot \nabla E$

502

$K_{\mathrm{e}}^{\mathrm{eo}}=K_{\mathrm{sat}}^{\mathrm{eo}} \cdot k_{\mathrm{rel}}=K_{\mathrm{sat}}^{\mathrm{eo}} \cdot S r^{3}$

503 where $K_{\mathrm{e}}^{\mathrm{h}}$ is the effective hydraulic permeability, which is calculated by Eq (A6), $K_{\text {sat }}^{\mathrm{h}}$

504 is the saturated permeability and $k_{\text {rel }}$ is relative permeability. $K_{\mathrm{e}}^{\mathrm{eo}}$ is the effective electro-

505 osmotic permeability, which is estimated by Eq (A8), and $K_{\text {sat }}^{\mathrm{eo}}$ is the saturated electro-

506 osmotic permeability. Both relative permeability are calculated using a model Brooks and

507 Corey [61] with an exponent of 3. Additionally, $\nabla$ is the gradient differential operator, $g$

508 is gravity, $z$ is the vertical coordinate, $E$ is the electric potential.

\section{A.2. Reactive transport}

510 The geochemical model implemented in M4EKR module contemplates $J$ components

511 which is capable of generating a sum of $\mathrm{N}$ chemical species for the chemical reactions

512 system considered (See Table 4) [62]. Thus, to determine the total chemical composition

513 of the system, it is necessary to calculate the total mass of each component $j(j=1 \ldots J)$

514 using a general mass balance equation, Eq (A.9). However, it is not required to solve $\mathbf{J}$

515 mass balances, only $J$-2 partial differential equations are necessary to compute, due to the

516 mass of one of the components is obtained applying the electroneutrality condition and

517 water mass is calculated by Eq. (A.1).

$518 \quad \frac{\partial m_{\mathrm{j}}}{\partial t}+\nabla \cdot \mathbf{1}_{\mathrm{j}}=R_{\mathrm{j}}$

519 where $m_{\mathrm{j}}$ is the total mass of component $j$ per unit total volume $\left(\mathrm{mol} \mathrm{m}^{-3}\right), \mathbf{l}_{\mathrm{j}}$ is its total 520 molar flux $\left(\mathrm{mol} \mathrm{m}^{-2} \mathrm{~s}^{-1}\right)$ which is defined as the sum of the contributions of four transport

521 processes: advective transport generated by (i) hydraulic, (ii) electroosmotic and (iii) 
522 electromigration fluxes, and (iv) Fickian diffusive-dispersive transport; and $R_{\mathrm{j}}$ is its rate

523 of production or consumption $\left(\mathrm{mol} \mathrm{m}^{-3} \mathrm{~s}^{-1}\right)$. Only $J-2$ partial differential equations are

524 required to be resolved, due to the total mass of one of the components is computed after

525 electroneutrality and the total mass of water is calculated by Eq. (A.1).

526 The resolution of the chemical speciation has been obtained applying a classical

527 stoichiometric approach based on to solve a system of mass-balance and mass-action

528 equations [63]. The general algorithm of this method has been described in detail in

529 literature [52, 62, 64, 65], even so the explicit formulation utilized in M4EKR can be seen

530 in previous works $[26,37]$.

\section{A.3. Electric charge balance}

532 The balance equation of the total electric charge is defined by the expression Eq. (A.10)

533 assuming that the electroneutrality condition is fulfilled throughout the entire domain and

534 the system the system is not able to accumulate electric charge.

$535 \nabla \cdot \mathbf{i}=0$

536 where $\mathbf{i}$ is the total current density $\left(\mathrm{A} \mathrm{m}^{-2}\right)$, which is estimated according Ohm's law [26,

537 66]. Rhoades [67] and Appelo [68] approaches are applying to calculated the apparent 538 electrical conductivity of the soil and electrical conductivity of pore water respectively.

539 The equations of these methods can be found in López-Vizcaíno et al. ([26].

540 A.4. Mass balance in electrolyte wells

541 The temporal evolution of the mass of the $J$ components is obtained solving $J-2$ balance

542 equations, Eq. (A.11) in each electrolyte compartment. The "ideal continuous stirring

543 tank reactors" assumption is supposed in both electrolyte compartments.

$544 \frac{d M_{j}^{*}}{d t}=\dot{M}_{j}^{i n, *}-\dot{M}_{j}^{o u t, *}+R_{j}^{*}$ 
545 where $M_{j}^{*}$ is the total mass of component $j(\mathrm{~mol})$ and $\dot{M}_{j}$ denotes the mass flow of

546 component $j\left(\mathrm{~mol} \mathrm{~s}^{-1}\right)$, being an input flow (superscript in) or output flow (superscript

547 out). Additionally, $R_{j}^{*}$ is the production/consumption/ term (mol s $\mathrm{s}^{-1}$ ) linked to the

548 electrochemical reactions (only water electrolysis). The superscript $*$ indicates the kind

549 of electrolyte compartment, which is AC or CC (anolyte or catholyte compartment

550 respectively). The equations employed to estimate these variables can be found in a 551 previous work $[26,36,37]$.

552 
554 [1] Y.B. Acar, Principles of electrokinetic remediation, Environment Science Technology, 27

555 (1993) 2638-2647.

556 [2] Y.B. Acar, R.J. Gale, A.N. Alshawabkeh, R.E. Marks, S. Puppala, M. Bricka, R. Parker,

557 Electrokinetic remediation: Basics and technology status, J. Hazard. Mater., 40 (1995) 117-137.

558 [3] J. Virkutyte, M. Sillanpaa, P. Latostenmaa, Electrokinetic soil remediation - critical overview,

559 Sci. Total Environ., 289 (2002) 97-121.

560 [4] K.R. Reddy, C. Cameselle, Electrochemical Remediation Technologies for Polluted Soils,

561 Sediments and Groundwater, John Wiley and Sons, 2009.

562 [5] D.H. Kim, B.G. Ryu, S.W. Park, C.I. Seo, K. Baek, Electrokinetic remediation of Zn and Ni-

563

564

565

566

567

568

569 contaminated soil, J. Hazard. Mater., 165 (2009) 501-505.

[6] L.M. Ottosen, H.K. Hansen, A.B. Ribeiro, A. Villumsen, Removal of $\mathrm{Cu}, \mathrm{Pb}$ and $\mathrm{Zn}$ in an applied electric field in calcareous and non-calcareous soils, J. Hazard. Mater., 85 (2001) 291299.

[7] M. Mascia, S. Palmas, A.M. Polcaro, A. Vacca, A. Muntoni, Experimental study and mathematical model on remediation of $\mathrm{Cd}$ spiked kaolinite by electrokinetics, Electrochimica Acta, 52 (2007) 3360-3365.

570 [8] M. Zhou, J. Xu, S. Zhu, Y. Wang, H. Gao, Exchange electrode-electrokinetic remediation of Cr-contaminated soil using solar energy, Separation and Purification Technology, 190 (2018) 297-306.

[9] M. Pazos, E. Rosales, T. Alcántara, J. Gómez, M.A. Sanromán, Decontamination of soils containing PAHs by electroremediation: A review, J. Hazard. Mater., 177 (2010) 1-11.

[10] J.N. Hahladakis, N. Lekkas, A. Smponias, E. Gidarakos, Sequential application of chelating agents and innovative surfactants for the enhanced electroremediation of real sediments from toxic metals and PAHs, Chemosphere, 105 (2014) 44-52.

[11] E. Bocos, C. Fernández-Costas, M. Pazos, M.Á. Sanromán, Removal of PAHs and pesticides from polluted soils by enhanced electrokinetic-Fenton treatment, Chemosphere, 125 (2015) 168174.

[12] E. Méndez, J.A. García, G. Hernández, S. Solís, F. Prieto, S. Pamukcu, E. Bustos, Study of electrochemical removal of phenanthrene in bentonite clay by physicochemical indicators, Separation and Purification Technology, (2018).

[13] I.M.V. Rocha, K.N.O. Silva, D.R. Silva, C.A. Martínez-Huitle, E.V. Santos, Coupling electrokinetic remediation with phytoremediation for depolluting soil with petroleum and the use of electrochemical technologies for treating the effluent generated, Separation and Purification Technology, (2018).

[14] A.B. Ribeiro, J.M. Rodriguez-Maroto, E.P. Mateus, H. Gomes, Removal of organic contaminants from soils by an electrokinetic process: the case of atrazine. Experimental and modeling, Chemosphere, 59 (2005) 1229-1239.

[15] A.B. Ribeiro, E.P. Mateus, J.M. Rodríguez-Maroto, Removal of organic contaminants from soils by an electrokinetic process: The case of molinate and bentazone. Experimental and modeling, Separation and Purification Technology, 79 (2011) 193-203.

[16] M.A. Rodrigo, N. Oturan, M.A. Oturan, Electrochemically assisted remediation of pesticides in soils and water: a review, Chemical reviews, 114 (2014) 8720-8745.

[17] E. Vieira dos Santos, C. Sáez, P. Cañizares, C.A. Martínez-Huitle, M.A. Rodrigo, Reversible electrokinetic adsorption barriers for the removal of atrazine and oxyfluorfen from spiked soils, J. Hazard. Mater., 322 (2017) 413-420.

[18] E. Vieira dos Santos, F. Souza, C. Saez, P. Cañizares, M.R.V. Lanza, C.A. Martinez-Huitle, M.A. Rodrigo, Application of electrokinetic soil flushing to four herbicides: A comparison, Chemosphere, 153 (2016) 205-211.

[19] J.M. Paz-Garcia, K. Baek, I.D. Alshawabkeh, A.N. Alshawabkeh, A generalized model for transport of contaminants in soil by electric fields, Journal of Environmental Science and Health - Part A Toxic/Hazardous Substances and Environmental Engineering, 47 (2012) 308-318. 

remediation of high sorption capacity soil, J. Hazard. Mater., 55 (1997) 203-220.

[21] K.R. Reddy, U.S. Parupudi, S.N. Devulapalli, C.Y. Xu, Effects of soil composition on the removal of chromium by electrokinetics, J. Hazard. Mater., 55 (1997) 135-158.

[22] A.Z. Al-Hamdan, K.R. Reddy, Geochemical assessment of metal transport in glacial till during electrokinetic remediation, Environmental Monitoring and Assessment, 139 (2008) 137149.

[23] A.Z. Al-Hamdan, K.R. Reddy, Transient behavior of heavy metals in soils during electrokinetic remediation, Chemosphere, 71 (2008) 860-871.

[24] Y.B. Acar, R.J. Gale, G.A. Putnam, J. Hamed, R.L. Wong, Electrochemical processing of soils: Theory of ph gradient development by diffusion, migration, and linear convection, J.

617

618

619

620

621

622

623

624

625

626

627

628 Environ. Sci. Health Part A Environ. Sci. Eng. Toxic Hazard. Subst. Control, 25 (1990) 687-714. [25] P.R. Bloom, U. Skyllberg, Soil pH and pH Buffering, in: P.M. Huang, Y. Li, M.E. Sumner (Eds.) Handbook of Soil Science, CRC Press, USA, 2012, pp. 333-352.

[26] R. López-Vizcaíno, A. Yustres, M.J. León, C. Saez, P. Cañizares, M.A. Rodrigo, V. Navarro, Multiphysics Implementation of Electrokinetic Remediation Models for Natural Soils and Porewaters, Electrochimica Acta, 225 (2017) 93-104.

[27] C. Risco, R. López-Vizcaíno, C. Sáez, A. Yustres, P. Cañizares, V. Navarro, M.A. Rodrigo, Remediation of soils polluted with 2,4-D by electrokinetic soil flushing with facing rows of electrodes: A case study in a pilot plant, Chem. Eng. J., 285 (2016) 128-136.

[28] C. Risco, S. Rodrigo, R. López-Vizcaíno, C. Sáez, P. Cañizares, V. Navarro, M.A. Rodrigo, Electrokinetic flushing with surrounding electrode arrangements for the remediation of soils that are polluted with 2,4-D: A case study in a pilot plant, Sci. Total Environ., 545-546 (2016) 256265.

629 [29] C. Risco, S. Rodrigo, R. López-Vizcaíno, A. Yustres, C. Sáez, P. Cañizares, V. Navarro, 630 M.A. Rodrigo, Electrochemically assisted fences for the electroremediation of soils polluted with 2,4-D: A case study in a pilot plant, Separation and Purification Technology, 156, Part 2 (2015) 234-241.

[30] R. López-Vizcaíno, V. Navarro, M.J. León, C. Risco, M.A. Rodrigo, C. Sáez, P. Cañizares, Scale-up on electrokinetic remediation: Engineering and technological parameters, J. Hazard. Mater., 315 (2016) 135-143.

[31] R. López-Vizcaíno, C. Risco, J. Isidro, S. Rodrigo, C. Saez, P. Cañizares, V. Navarro, M.A. Rodrigo, Scale-up of the electrokinetic fence technology for the removal of pesticides. Part I: Some notes about the transport of inorganic species, Chemosphere, 166 (2017) 540-548.

[32] R. López-Vizcaíno, C. Risco, J. Isidro, S. Rodrigo, C. Saez, P. Cañizares, V. Navarro, M.A.

641

642

643

644

645

646

647

648

649

650

651

652

653 Rodrigo, Scale-up of the electrokinetic fence technology for the removal of pesticides. Part II: Does size matter for removal of herbicides?, Chemosphere, 166 (2017) 549-555.

[33] C. Risco, S. Rodrigo, R. López Vizcaíno, A. Yustres, C. Saez, P. Cañizares, V. Navarro, M.A. Rodrigo, Removal of oxyfluorfen from spiked soils using electrokinetic soil flushing with linear rows of electrodes, Chem. Eng. J., 294 (2016) 65-72.

[34] C. Risco, H. Rubí-Juárez, S. Rodrigo, R. López Vizcaíno, C. Saez, P. Cañizares, C. BarreraDíaz, V. Navarro, M.A. Rodrigo, Removal of oxyfluorfen from spiked soils using electrokinetic fences, Separation and Purification Technology, 167 (2016) 55-62.

[35] C. Risco, H. Rubí-Juárez, S. Rodrigo, R. López-Vizcaíno, C. Saez, P. Cañizares, C. BarreraDíaz, V. Navarro, M.A. Rodrigo, Removal of oxyfluorfen from spiked soils using electrokinetic soil flushing with the surrounding arrangements of electrodes, Sci. Total Environ., 559 (2016) 94102.

[36] R. López-Vizcaíno, A. Yustres, L. Asensio, C. Saez, P. Cañizares, M.A. Rodrigo, V. Navarro, Enhanced electrokinetic remediation of polluted soils by anolyte pH conditioning, Chemosphere, 199 (2018) 477-485.

655 [37] R. López-Vizcaíno, A. Yustres, C. Sáez, P. Cañizares, M.A. Rodrigo, V. Navarro, Effect of 656 polarity reversal on the enhanced electrokinetic remediation of 2,4-D-polluted soils: A numerical 657 study, Electrochimica Acta, (2017). 

transport in electrokinetic remediation of unsaturated kaolinite. Experimental and numerical study, Separation and Purification Technology, 192 (2018) 196-204.

661

662

663

664

665

666 [39] L.N. Plummer, T.M.L. Wigley, D.L. Parkhurst, Kinetics of calcite dissolution in CO2-water system at $5^{\circ}$ to $60^{\circ} \mathrm{C}$ and 0.0 to $1.0 \mathrm{~atm}$ CO2, Am J Sci, 278 (1978) 179-216.

[40] W. Stumm, J.J. Morgan, Aquatic chemistry: chemical equilibria and rates in natural waters, Wiley, 1996.

[41] A.C. Lasaga, Kinetic Theory in the Earth Sciences, Princeton University Press, Princeton, NJ, USA, 1998.

667 [42] N.C.M. Marty, F. Claret, A. Lassin, J. Tremosa, P. Blanc, B. Madé, E. Giffaut, B. Cochepin,

668 C. Tournassat, A database of dissolution and precipitation rates for clay-rocks minerals, Applied 669 Geochemistry, 55 (2015) 108-118.

670 [43] E. Giffaut, M. Grivé, P. Blanc, P. Vieillard, E. Colàs, H. Gailhanou, S. Gaboreau, N. Marty,

671 B. Madé, L. Duro, Andra thermodynamic database for performance assessment: ThermoChimie,

672 Applied Geochemistry, 49 (2014) 225-236.

673 [44] A. COMSOL, COMSOL Multiphysics Reference Manual Version: COMSOL 5.1., (2015).

674 [45] Ö. Babur, V. Smilauer, T. Verhoeff, M. Van Den Brand, A survey of open source multiphysics frameworks in engineering, in: Procedia Computer Science, 2015, pp. 1088-1097. [46] D.L. Brown, J. Bell, D. Estep, W. Gropp, B. Hendrickson, S. Keller-McNulty, D. Keyes, J.T. Oden, L. Petzold, M. Wright, Applied Mathematics at the U.S. Department of Energy: Past, Present and a View to the Future, Applied Mathematics at the U.S. Department of Energy: Past, Present and a View to the Future, (2008).

680 [47] D.E. Keyes, L.C. McInnes, C. Woodward, W. Gropp, E. Myra, M. Pernice, J. Bell, J. Brown, 681 A. Clo, J. Connors, E. Constantinescu, D. Estep, K. Evans, C. Farhat, A. Hakim, G. Hammond, 682 G. Hansen, J. Hill, T. Isaac, X. Jiao, K. Jordan, D. Kaushik, E. Kaxiras, A. Koniges, K. Lee, A. 683 Lott, Q. Lu, J. Magerlein, R. Maxwell, M. McCourt, M. Mehl, R. Pawlowski, A.P. Randles, D. 684 Reynolds, B. Rivière, U. Rüde, T. Scheibe, J. Shadid, B. Sheehan, M. Shephard, A. Siegel, B. 685 Smith, X. Tang, C. Wilson, B. Wohlmuth, Multiphysics simulations: Challenges and opportunities, International Journal of High Performance Computing Applications, 27 (2013) 483.

[48] J. Carrayrou, R. Mosé, P. Behra, Operator-splitting procedures for reactive transport and comparison of mass balance errors, Journal of Contaminant Hydrology, 68 (2004) 239-268.

[49] D. Jacques, J. Šimůnek, D. Mallants, M.T. van Genuchten, Operator-splitting errors in coupled reactive transport codes for transient variably saturated flow and contaminant transport in layered soil profiles, Journal of Contaminant Hydrology, 88 (2006) 197-218.

[50] J.M. Paz-García, B. Johannesson, L.M. Ottosen, A.N. Alshawabkeh, A.B. Ribeiro, J.M. Rodríguez-Maroto, Modeling of electrokinetic desalination of bricks, Electrochimica Acta, 86 (2012) 213-222.

696 [51] M.T. van Genuchten, CLOSED-FORM EQUATION FOR PREDICTING THE 697 HYDRAULIC CONDUCTIVITY OF UNSATURATED SOILS, Soil Science Society of 698 America Journal, 44 (1980) 892-898.

699 [52] D.L. Parkhurst, C.A.J. Appelo, User's guide to PHREEQ C (Version 2) - a computer program for speciation, batch-reaction, one-dimensional transport and inverse geochemical calculations, Water-Resources Investigations, Report 99-4259, Denver, Co, USA, (1999) 312.

[53] M.J. Pikal, Ion-pair formation and the theory of mutual diffusion in a binary electrolyte, The Journal of Physical Chemistry, 75 (1971) 663-675.

[54] M. Villen-Guzman, J.M. Paz-Garcia, G. Amaya-Santos, J.M. Rodriguez-Maroto, C. VeredaAlonso, C. Gomez-Lahoz, Effects of the buffering capacity of the soil on the mobilization of heavy metals. Equilibrium and kinetics, Chemosphere, 131 (2015) 78-84.

[55] R. López-Vizcaíno, J. Alonso, P. Cañizares, M.J. León, V. Navarro, M.A. Rodrigo, C. Sáez, Electroremediation of a natural soil polluted with phenanthrene in a pilot plant, J. Hazard. Mater., 265 (2014) 142-150.

711 Chemical Engineering Science, 53 (1998) 3863-3874. 
712 [57] A.Z. Al-Hamdan, K.R. Reddy, Electrokinetic remediation modeling incorporating 713 geochemical effects, J. Geotech. Geoenviron. Eng., 134 (2008) 91-105.

714 [58] M.T. van Genuchten, A Closed-form Equation for Predicting the Hydraulic Conductivity of 715 Unsaturated Soils1, Soil Science Society of America Journal, 44 (1980) 892-898.

716 [59] N. Edlefsen, A. Anderson, Thermodynamics of soil moisture, Hilgardia 15 (2) (1943) 31717298.

718 [60] J.K. Mitchell, K. Soga, Fundamentals of soil behavior, John Wiley \& Sons, Inc, Hoboken, 719 New Jersey, USA, 2005.

720 [61] R.H. Brooks, A.T. Corey, Hydraulic Properties of Porous Media, Colorado State University, 7211964.

722 [62] C.M. Bethke, Geochemical and Biogeochemical Reaction Modeling, Cambridge University 723 Press, 2007.

724 [63] A.M.M. Leal, M.J. Blunt, T.C. LaForce, Efficient chemical equilibrium calculations for 725 geochemical speciation and reactive transport modelling, Geochimica et Cosmochimica Acta, 131 726 (2014) 301-322.

727 [64] C.I. Steefel, C.A.J. Appelo, B. Arora, D. Jacques, T. Kalbacher, O. Kolditz, V. Lagneau, P.C. 728 Lichtner, K.U. Mayer, J.C.L. Meeussen, S. Molins, D. Moulton, H. Shao, J. Šimůnek, N. Spycher, 729 S.B. Yabusaki, G.T. Yeh, Reactive transport codes for subsurface environmental simulation, 730 Computational Geosciences, 19 (2015) 445-478.

731 [65] P.C. Lichtner, Continuum model for simultaneous chemical reactions and mass transport in 732 hydrothermal systems, Geochimica et Cosmochimica Acta, 49 (1985) 779-800.

733 [66] R.A. Jacobs, R.F. Probstein, Two-Dimensional Modeling of Electroremediation, AIChE 734 Journal, 42 (1996) 1685-1696.

735 [67] J.D. Rhoades, N.A. Manteghi, P.J. Shouse, W.J. Alves, Soil Electrical Conductivity and Soil

736 Salinity: New Formulations and Calibrations, Soil Science Society of America Journal, 53 (1989)

$737 \quad 433-439$.

738 [68] C.A.J. Appelo, Specific conductance: how to calculate, to use, and the pitfalls, in, 2010. 